\title{
Being with Technique-Technique as being-with: The technological communities of Gilbert Simondon
}

\author{
Susanna Lindberg ${ }^{1} \mathbb{D}$ \\ Published online: 8 June 2019 \\ (C) The Author(s) 2019
}

\begin{abstract}
I present Gilbert Simondon's thinking of technics, that I take to be so compelling today because it articulates technological reality in ecological terms as a technogeography and life as being-with-the-machines. I will (1) flesh out Simondon's program for a being-with-the-machines, (2) show how it corresponds to the essence of the technical objects described in terms of milieu and relation (3) indicate how this is based on Simondon's ontology of individuation (4) suggest a criticism of Simondon, insofar as he would underestimate the technicality of the human being him/ herself and of his/her world.
\end{abstract}

Keywords Simondon · Technics · Technology · Technogeography · Milieu • Individuation

Since some years, a promise of Simondon is in the air: All of his works are at last being published in French, his main works are being translated into English, and commentaries appear also in English. ${ }^{1}$ What is compelling today about this thinker of technology and of individuation that inspired for instance Deleuze, Latour, Stengers and Stiegler?

I think that our time is compelled by Simondon's thinking of technological reality in ecological terms as a techno-geography and of life as a being-with-the-machines. In this article, I will outline Simondon's program for a being-with-the-machines; show how it corresponds to the essence of the technical objects described in terms of milieu and relation; indicate how this is based on Simondon's ontology of individuation; and suggest a criticism of Simondon, insofar as he would underestimate the inevitable technicality of the human being him/herself and of his/her world.

\footnotetext{
1 see, e.g. Parrhesia 07; de Boever et al. (2012); Scott (2014).
}

Susanna Lindberg

susanna.e.lindberg@gmail.com

1 Collegium for Advanced Studies of the University of Helsinki, University of Helsinki, Po.Box 3, 00014 Helsinki, Finland 
(1) In Penser la connaissance et la technique après Simondon, Jean-Hugues Barthélémy shows that Simondon thinks the technical object as support and symbol of the transindividual relation. ${ }^{2}$ Being the support of this relation, the object is precisely not the foundation of a community but the intermediary of transindividual relations. The relation it mediates is transindividual, that is to say, it does not connect already constituted individuals but expresses the pre-individual reality thanks to which individuations can take place. But technical objects do not only enable human being-with: They are also something with which human beings exist, so that human beings are engaged in specific ways of being-with-technical objects.

In the Introduction of Du mode d'existence des objets techniques (1958), Simondon tells what the human being's relation to machines should be:

The machine endowed with a high degree of technicity is an open machine, and all open machines taken together [l'ensemble des machines ouvertes] presuppose man as their permanent organizer, as the living interpreter of all machines among themselves. Far from being the supervisor of a group of slaves, man is the permanent organizer of a society of technical objects that need him in the same way musicians in an orchestra need the conductor. [...] Man thus has the function of being the permanent coordinator and inventor of the machines that surround him. He is among the machines that operate with him..$^{3}$

The human being is among and with machines: His/her relation to technical objects is not explained in terms of instrumentality but expressed in terms of community or being-with. ${ }^{4}$ This is an invitation to understand technical objects better than technophobic humanists and technophilic technocrats do, for they examine technical objects in terms of something that they are not (instruments of human needs/applications of scientific theories) instead of what they are in themselves. But this is above all an invitation to construct a better practical relation to technical objects.

The human being's being with technical objects is distinct from his/her beingwith other human beings, animals or natural beings especially because the technical object is the mediator of other types of being-with. Throughout history, the human being has had different ways of being-with-the-technical-object, that Simondon presents schematically through the figures of the craftsman, the engineer, and the technician. The first two are specifically contrasted by Simondon to the attitude that he is promoting.

\footnotetext{
2 Barthélémy (2005, p. 142).

${ }^{3}$ Simondon (2017, pp.17-18). Simondon's book Du mode d'existence des objets techniques was first published in 1958 and reprinted in 2012. Its English translation by Cecile Malaspina and John Rogrove, On the Mode of Existence of Technical Objects, only appeared in 2017, the original page numbers are indicated at the margins of the translation.

${ }^{4}$ Simondon actually rejects the term "community" (Simondon 2013, pp. 341-343). Simondon follows André Leroi-Gourhan's way of thinking techniques in terms of "technical tendencies" that go over particular "communities," understood as closed ethnies, and open up a more universal "civilization" instead. See e.g. Leroi-Gourhan (1973, pp. 336 s.q.q).
} 
Firstly, the craftsman surely has an "authentic" relation to the technical object insofar as his/her knowledge of the "elements" of his/her work (water, earth, wood...) is profound and s/he masters a great number of skills that are available in his/her situation. At least $\mathrm{s} / \mathrm{he}$ is a far more accomplished technician than a factory worker. Nevertheless, Simondon characterizes the craftsman's situation as "infancy" of technique: the craftsman has learned his/her craft by doing, s/he has learned it unconsciously and unreflectively like the child learns to walk and talk, and this is why it is difficult for her/him to transfer his/her skills into other situations or to invent new crafts. ${ }^{5}$ On the contrary, reflexivity and the ensuing plasticity characterize the "adult" relation to technique, that is most visible in the engineer. (In the context of education, Simondon's understanding of infancy is clearly outdated ${ }^{6}$ but here this is irrelevant, since he refers to the terms "minority" and "majority" as they are used by Kant in "What is Enlightenment?")

Secondly, the engineer is not the perfect technician either, since in the modern industrial world s/he is often just as alienated as the factory worker and the capitalist, who figure alienation from work in the first place. ${ }^{7}$ None of them relates to the technical object as such, but only in function of its economical value. Simondon criticizes alienation in the industrial world in another way than Heidegger ${ }^{8}$ and $\operatorname{Marx}^{9}$ : Against their claim that technique alienates man, ${ }^{10}$ Simondon claims that modern alienation is man's alienation from the machine and the machine's own alienation of what it can really do and how it can evolve towards new uses.

Thirdly, the authentic technician's role is to overcome both the infancy (preindustrial society) and the alienation (industrial society) by learning to live with the machines. The technician is the "pure individual," whose task is above all to understand machines. ${ }^{11}$ Firstly, s/he interprets and invents machines. The machine shouldn't be for him/her a "black box" whose input and output are known but whose functioning remains mysterious: ${ }^{12}$ A real technician understands the functioning of technical objects and invents new ways of functioning. Secondly, s/he shouldn't direct machines from above: "Technical life, however, does not consist in overseeing machines, but in existing at the same level as a being that takes charge of the relation between them, capable of being coupled, simultaneously or successively, with several machines." ${ }^{13}$ Instead of merely directing machines, s/he should interpret and

\footnotetext{
5 Simondon (2017, pp. 106-109).

6 see e.g. Simondon (2014, pp. 43-46, 203-232).

7 Simondon (2017, pp. 134, 140-141).

8 Simondon accuses Heidegger of analyzing alienation only in terms of the "use" of the Zeug (Simondon 2017: 230; Simondon 2014: 31). Simondon's interpretation of Heidegger's thinking of technology is insufficient, because he only pays heed to Being and Time. On Simondon's relation to Heidegger, see Vaysse (2006), Combes (2006), and Barthélémy (2015, pp. 47-71).

9 Simondon accuses Marx of analyzing alienation only in terms of "work" (Simondon 2017, p. 231; Simondon 2014, pp. 54 s.q.q.).

10 Xavier Guchet presents the general debate on man's enslavement by the macine at the time of the preparation of Du mode d'existence des objets techniques in Guchet (2010, pp. 133-136).

11 Simondon (2013, pp. 340-341).

12 Combes (2006).

13 Simondon (2017, p. 140).
} 
translate them to one another so as to construct better technical ensembles, milieux and "techno-geographic milieus"-techno-geographic milieu being the simultaneously technological and geographical milieu that the object projects as its condition. ${ }^{14}$ Thirdly, s/he should interpret machines to "artists and thinkers" and to all who find themselves ignorant about machines, ${ }^{15}$ and in this sense fulfil a social role as well. Simondon's searching for the authentic technician sometimes looks like calling forth new specialists rather than democratizing technological competences, but this impression must be nuanced. Finally, the aim of technical thinking is the invention of new ways of being-with-other-people as well:

Technical thought is present in all technical activity, and technical thought is of the order of invention; it can be communicated; it authorizes participation. [...] The technical object insofar as it has been invented, thought and willed, and taken up by a human subject, becomes the medium [support] and symbol of this relation ship, which we would like to name transindividual. ${ }^{16}$

Here we see how the genuine technological community becomes a model of being-with-others that, according to Simondon, should be neither collective nor intersubjective but "transindividual." A "transindividual" relation to other people is not a collective submission to a single principe, nor an intersubjective relation between already constituted individuals, but a transindividual relation in which individualisation is perpetuated from an individual to another laterally. ${ }^{17}$

A pure technician "respects" the technical object. ${ }^{18}$ Through him/her, the object is "liberated" and even "saved" from its "enslavement" to pure utility (the idea of "salvation" of technical object is presented in an interview with Anne Kéhickian "Sauver l'objet technique" "19). No more a "black box," it ceases to be a "closed machine" that refuses all modifications, and becomes an "open machine" that can be repaired, transformed and used as material for new inventions: The "authentic technical object" is free to evolve. ${ }^{20}$

(2) The technical object as such is a relation and a being-with, ${ }^{21}$ and this is precisely why it can be "free," "open" and "authentic." Simondon presents the

\footnotetext{
14 Simondon (2017, p. 58).

15 Simondon (2017, pp. 162-163).

16 Simondon (2017, p. 252).

17 Chateau (2008, pp. 57-61).

18 Simondon (2014, p. 204).

19 Simondon (2014, pp. 447-454).

20 Simondon celebrates concrete manual work with machines and speaks with genuine joy of building tv sets and other machines with schoolchildren. In this regard, he has a similar mentality as Matthew Crawford in his Shop Class as Soulcraft: An Inquiry Into the Value of Work, Penguin Press (2009), although philosophically Crawford rather reminds of Thoreau, not of Simondon.

21 "Without a doubt, the ontological postulate, or rather, the ontogenetic postulate, central to a philosophy of individuation, is that individuals consist in relations, and as a consequence, relation has the status of being and constitutes being" (Combes 2013, p. 21). See also Jean-Hugues Barthélémy's Simondon which is a very good presentation of Simondon's philosophy in general as a philosophy of relation, see in particular Barthélémy (2014, pp. 79-94).
} 
relationality of technical objects both through the history of technology and in abstract philosophical terms.

Actually Simondon starts his history of technologies from biology. Following the ethological and the ecological tradition that originates from the works of Jacob von Uexküll, Simondon thinks technical reality as a mode of the type of relation that a living being has to its milieu. ${ }^{22}$ It may go without saying that simple tools and instruments constitute mediations between human beings and their milieux ${ }^{23}$ (or animals and their milieux, Simondon does not exclude animal technologies). But particularly the history of human technologies shows that the technical object is also a relation in itself. More interesting for Simondon than simple tools are complicated technical objects like apparatuses and machines that function by themselves by reacting and relating to their own functioning through various mechanisms of auto-regulation and auto-correlation. Of course, such automats were first studied in cybernetics-but Simondon thinks that Norbert Wiener's cybernetics is too limited a theory because it examines automats too exclusively as if they were entirely closed systems while, in reality, a pure automat does not exist, because all technical objects are embedded in their technogeographical milieus with which they exchange information. ${ }^{24}$ It is remarkable that already in 1968-1969, for instance in his lecture course L'invention et le développement des techniques, he presents as the most advanced and interesting kind of technology the information and telecommunication technologies that function through "programs" and are organised as "networks" between "terminals," that modulate the "texture" of the original milieu, and core elements that "represent for the first time pure technicity". ${ }^{25}$ Such networks are of course essentially relational entities: The solitary material terminal (telephone, TV set, computer) separated from the network is practically useless.

In abstract philosophical terms, any technical object is firstly a relation with itself. It is a being-with-itself in its functioning, because by functioning it relates to itself. For Simondon, the technical object is not a material thing but a functioning: "The machine is a being that functions". ${ }^{26}$ The technical object is not the double of the human hand but of the action made by the hand: "What resides in the machines is human reality, human gesture fixed and crystallized into working structures [structures qui fonctionnent]" 27 or "The machine is a deposited fixed human gesture that has become a stereotypy and the power to restart". ${ }^{28}$ The functioning technical object also relates to itself, for instance when its fabricant and user gradually adapt it to specific tasks. "The technical being evolves through convergence and self-adaption: It unifies itself internally according to a principle of inner resonance."29

\footnotetext{
22 Simondon (2005, p. 85), and Introduction by Chateau to Simondon (2005, p. 50).

23 Simondon (2005, p. 89).

${ }^{24}$ Simondon (2005, pp. 89, 93, 94), Simondon (2017, p. 51).

25 Simondon (2005, pp. 98-101).

26 Simondon (2017, p. 151).

27 Simondon (2017, p. 18).

28 Simondon (2017, p. 151).

29 Simondon (2017, p. 26).
} 
Secondly, the technical object has a historical being-with-other-objects when it relates to other objects of its "lineage." The "individual technical object is not this or that thing, given hic et nunc, but that of which there is genesis": ${ }^{30}$ It is its genesis. The genesis of a technical object is the genesis of an entire lineage through which a "technical essence" gradually evolves. Technical objects exist as phylogenetic lines that deploy a kind of a history that starts by invention, not of a thing, but of a technical function, and not as a definite solution, but as a possible response to a problem. Simondon does not think invention primarily as man's act but as inventivity that comes from the object itself: This is why its openness is so important. From then on, the technical object evolves by engendering new variants of the same principle or by incorporating the principle into new combinations. Simondon understands the technical object "through phenomena for which it is in itself the basis: This is where its fecundity comes from, a non-saturation giving it posterity" [...] "One could say that the technical object evolves by generating a family: The primitive object is the ancestor of this family. Such evolution could be called a natural technical evolution". ${ }^{31}$ However, biology only provides an analogy and actually Simondon forbids to confound the technical object with a living being. ${ }^{32}$ Technical evolution is better compared to memory, so that technical memory conserves and repeats whatever contents are registered in it—while human memory forgets contents but is capable of recovering forms and introducing new codes. ${ }^{33}$ Even the "open machine" that allows new codings needs to receive these from humans.

The evolution of a technical object is its "concretization." A "primitive" technical object is "abstract:" An abstract object might be, for instance, a custom-made object that functions only in given circumstances. Concretized objects' elements fit together with other objects and function with them. Through concretization, they "prove the viability and the stability of a certain structure which has the same status as a natural structure:" It becomes the real world. The technical objet is no more world's artificial ornament but its supporting element.

Even though technical objects are gradually worn, corroded and deformed, they cannot die or be destroyed (persons and works of art can, because they are unique, while technical objects are replaceable instances of a type). Instead, a technical essence can become obsolete. In the lecture course Psychosociologie de la technicité, Simodon examines different aspects of obsolescence of technical objects. He thinks that technical objects are alienated and reduced to slavery when a perfectly functional machine is made obsolescent by extra-technical causes. ${ }^{34}$ On the contrary,

\footnotetext{
30 ibid., p. 26.

31 ibid., p. $45,46$.

32 ibid., p. 50.

33 ibid., pp. 135-138. Simondon's idea of technique has been interpreted as a kind of memory especially by Stiegler (1994, p. 81 s.q.q.). In living beings, memory is structured as mental schemes that can canalise action, but these structures are at the same time metastable and therefore changing. On the one hand, memory schemes are incorporated solutions to past problems, and on the other hand, encounter with an individuating event enables invention that modifies existing schemes. (Morizot 2016, p. 162-187). In the case of technical objects, evolution generally concerns technical essences, not individual objects.

34 Simondon (2014, pp. 54-62).
} 
an open machine can be repaired, its elements can be used in other technical ensembles: As long as its essence is non-saturated, it is fecund of new inventions.

Thirdly, the technical object is a spatial being-with-other-objects (and beings). It cannot be examined in isolation, because it is always a part of a world which consists of a natural site, of a social context, of economical conditions, of a technological environment, etc. Like all other objects, technical objects have a milieu and only make sense in the milieu. Furthermore, they open the milieu that the human being shares with other human, natural and technical beings.

The technical object "can adapt to the material and human conditions of production [...] it can then adapt to the task for which it is made." 35 It has a double relation to its surroundings because it relates both to natural conditions and to a technical environment and is their point of encounter. The human being's task is to invent the best possible compromise between the two worlds, and an advanced technology is characterized by the high adaptation of the technical world into the natural world. ${ }^{36}$

Adaptation-concretization is a process that conditions the birth of a milieu rather than being conditioned by an already given milieu; it is conditioned by a milieu that only exists virtually before invention; there is invention because there is a leap that takes place and is justified by means of the relation that it brings about within the milieu that it creates; [...] One could say that the concretizing invention realizes a techno-geographic milieu [...] which in turn is a condition of possibility of the technical object's functioning. The technical object is thus its own condition, as a condition of existence of this mixed milieu which is simultaneously both technical and geographical. ${ }^{37}$

Simondon calls "associated milieu" the techno-natural milieu that the technical objects create or project as their own elemental ground. ${ }^{38}$ Through the notion of the associated milieu Simondon defines the three modes of existence of the technical object, namely being as element, as individual and as ensemble. The technical individual is the proper incarnation of a technical essence; Simondon's own example is a Guimbal turbine, but to avoid lengthy technical explications, I choose an easier example - a piano. Simondon says that principally a technical individual is invented and has an "associated milieu," 39 for instance a concert hall. "We shall speak of a technical individual whenever the associated milieu exists as a condition of functioning sine qua non, whereas it is an ensemble in the contrary case." 40 The technical element is only a part, like the hammer of a piano. It does not have its own "associated milieu," and this is probably why it can be detached from the individual and eventually incorporated into a different technical individual (hence the discontinuities of technical evolution). "It is thus within elements that technicity

\footnotetext{
35 Simondon (2017, p. 53).

36 ibid., pp. 55-56.

37 ibid., p. 68.

38 ibid., p. 59, see also ibid., p. 208.

39 ibid., pp. 59, 73.

40 ibid., p. 63.
} 
exists in the purest way, in a free state as it were, whereas in the individual or the ensemble, technicity only exists in a state of combination," ${ }^{\prime 1}$ In elements, technicity exists therefore as a "transductive propriety" that can be transferred from an object to another. The technical ensemble does not have an "associated milieu:" It is a set of machines that operate together thanks to human coordination. There is a circulation between individual, element and ensemble: The individual is invented (piano), not out of nothing but out of available elements that carry the technicity of an epoch (hammers, strings). Thanks to the elements technicity can be transferred from an individual to another, and it is this transduction of elements rather than the sole act of inventing technical inventions that makes technical evolution possible.

(3) Simondon intends this "phenomenology" 42 of the technical object as a major example of the ontology of individuation that he exposes in L'individuation à la lumière des notions de forme et d'information-but the main reference of this book is biology — and Du mode d'existence des objets techniques does not explain its relation to L'individuation à la lumière des notions de forme et d'information. I cannot expose the ontology of individuation here in any detail, but for those who are already familiar with it, and also to indicate a direction of further research, I give a very brief outline of the reasons for which the technical object illustrates the main principles of this ontology. ${ }^{43}$ Inversely, the ontology of individuation explains the mode of being of technical objects.

Simondon's thinking of individuation is a thinking of real genetic transformation that is directed against atomism and hylomorphism. As Combes shows in her groundlaying book Gilbert Simondon and the Philosophy of the Transindividual, Simondon thinks individuation as a process in function of a preindividual being, which he defines against the idea of a unitary, identical Being as an excessive, metastable dimension of potentialities that can lead to different individuations without exhausting the preindividual. ${ }^{44}$

Accordingly, the technical essence does not precede technical objects, but invention is an ongoing process that happens gradually in the course of technical

\footnotetext{
41 ibid., p. 74.

42 Simondon's approach resembles phenomenology but he does not use the term himself, and speaks of a genealogical method instead. On these terms and their difference, see Chateau (2010). In a useful comparision of Simondon with Merleau-Ponty, Andrea Bardin resumes the difference between phenomenology and Simondon's thinking as follows: "[F]rom Simondon's perspective, even the more advanced of Merleau-Ponty's attempts cannot avoid the presupposition of sense. [...] Simondon, on the contrary, renews the concept of information in order to relegate perception, signification and sense to the domain of psychic and collective individuation, making them depend on ontogenesis itself and thus abandoning the phenomenological hierarchy still implicit in the choice of the term 'perception'." Bardin (2015, p. 42).

43 For a more thorough presentation of the ontology of individuation see Combes 2013; Scott 2014; Grosz 2012; Sauvagnargues 2012. Sauvagnargues's interpretation is important also because she indicates how Simondon's thinking has passed on to Deleuze. However, according to Barthélémy (2014, pp. 187-191), Deleuze has misinterpreted Simondon because he interprets Simondon's ontological field as a pre-personal transcendental field. The difference between Deleuze and Simondon would therefore be analogical to the difference between Merleau-Ponty and Simondon: Simondon is interested in ontological questions rather than epistemological ones, and this is why he does not study the constitution of subjectivity but the individuation that precedes any type of existence, including subjectivity.

44 Combes (2013, pp. 2-9).
} 
evolution. Actually there are no (technical) individuals but only processes of individuation. All (technical) objects are "metastable," that is to say they contain asymmetrical disequilibrium which causes tension and demands the invention of new solutions of equilibrium. A metastable situation projects a "pre-individual" situation in which invention happens: The pre-individual is a "materialist" ground (fond) that mustn't be understood as a metaphysical arche-matter but as a situation of dynamic possibilities that appear as differences, tensions, problems. This is well illustrated by technical invention which does not happen ex nihilo but by answering to concrete problems by new arrangements of elements that are already available in its "associative milieu." The elements themselves are not positive building blocks, but processes of "disparation," that is to say processes that repeat previous processes with a slight difference, thanks to which the eruption of the new becomes possible. This is how metastable processes pass by "transduction" to new individuals, "transduction" being a process in which an activity continues itself in its immediate vicinity by working and organising neighboring regions and by creating, in this way, new individuals that are similarly provisional unities of heterogeneous elements. Contrary to induction and deduction, transduction is not a theoretical mastery of a situation but an imaginative way of solving practical problems by transferring old elements into new individuals and by hereby changing the elements themselves.

All technical objects are "metastable," provisional beings. The technical lineages evolve through transductive events by integrating and transforming pre-individual elements into new technical individuals-which remain quite as problematic, provisional and changing as the preceding ones.

4) To end, I will outline a critizism of Simondon, insofar as he would underestimate the technicality of the human being him/herself and of his/her world, as well as its consequences to his ideal of knowledge.

Simondon opens the "black box" of technique wonderfully, but does he see the technicity of the human being him/herself? Of course, in his time, contemporary anthropotechnies (gene therapies, transplants, etc.) hardly existed, while they are becoming very important today. However, the point is not to discard Simondon's thinking together with the technologies that he studied, but to ask if his philosophy helps us to understand later techniques as well: If Gilbert Hottois is right in noting that Simondon does not really help in the understanding of contemporary anthropotechnics, ${ }^{45}$ this is not because he did not know of such technological possibilities but because his conception of humanity remains fairly traditional.

For instance Bernard Stiegler allows us to understand the philosophical roots of this. He has suggested that Simondon postulates a magical pretechnical origin of humanity, while there are good reasons to follow Leroi-Gourhan, instead, and define humanity as originarily technical. ${ }^{46}$ As a consequence of this, Simondon would end by presenting contemporary alienation as if it were a provisional state of affairs that could be overcome thanks to the work of authentic technicians who invent authentic machines that constitute a positive technogeographic milieu.

\footnotetext{
45 Hottois (2002, pp. 98-100).

46 Stiegler (2006, pp. 325-341).
} 
According to Barthélémy, this reading is only possible because Stiegler would interpret On the mode of existence of technical objects in the sense of a history of culture while it ought to be read as genetic eidetics. ${ }^{47}$ While this can be maintained in the case of On the mode..., ${ }^{48}$ the lecture course Psychosociologie de la technicite indicates that Simondon thinks technics and sacrality also in terms of their history. ${ }^{49}$ Stiegler thinks that Simondon's concepts are not sufficient to understand contemporary world which would be overdetermined by the increasing alienation of wo/ men caused by the overwhelming presence of factually alienated technique. ${ }^{50}$ Muriel Combes makes a parallel criticism when she says that Simondon fails to think toolless techniques that aim at particular forms of subjectivation and of transformation of self and world. ${ }^{51}$ Combes' examples are ascetic and shamanistic techniques of the self, but I think that the remark should be extended to techniques of the self in general, not only to the consciously built techniques described by Foucault, but to all habit-based skills starting from walking and talking. ${ }^{52}$ It seems to me that since the very beginning the human being is his/her first instrument, and because s/he does not invent this instrumentality alone but acquires it transindividually, his/her relation to it can never be entirely conscious, authentic, masterful. Linguistic or musical skills give excellent examples of this: Learning to speak a new language or to play an instrument is a transductive process that consists both of an "infantile" formation of a kind of an instinct and of an "adult" reflection on the process. It could be shown that one could never learn a language by applying seriously Simondon's theory of education, which is based on a clear distinction between irreflective infancy and reflective maturity. ${ }^{53}$

Among Simondon's most compelling ideas is his description of a techno-geographic milieu that allows to overcome the rigid opposition between a natural site and a technological context thanks to the mediation of the object. Indeed, in the contemporary world it seems increasingly impossible to draw a sharp line between nature and technology, for the two have merged into a single techno-nature in which nature is conditioned by technique as much as the technique by nature. But how

\footnotetext{
47 Barthélémy (2014, p. 167, 2016).

48 Simondon (2017, p. 167).

49 Simondon (2014, pp. 73-129).

50 Alienation is for Simondon essentially the alienation of the technical object itself. "A control panel and command buttons are enough in an alienated machine" (Simondon 2014, p. 69) while the user can see, understand and even modify the functioning of an open machine. Now, is it sure that we want to see to the functioning of all the machines that we use? Don't we on the contrary ask for ever simpler cell phones and laptops so that we can precisely forget about their functioning? Simondon and Stiegler have good reasons for saying that alienated machines are out of our control and actually control us: But is a truly authentic machine possible? Or if not, are we condamned to the monstruous task of trying to determine a tolerable degree of alienation?

51 Combes (2006, p. 98).

52 For Andre Leroi-Gourhan, the tool is the origin of man, and the tool is possible because of the upright position and short face, that is to say, as soon as man walks and talks. See p. ex. Leroi-Gourhan (1964, pp. 32 s.q.q., 129). Simondon knew Leroi-Gourhan's earlier works and appreciated them. Perhaps $D u$ mode d'existence des objets techniques would have been anthropologically richer had he been able to read Le Geste et la parole that was published only in 1964.

53 Simondon (2017, pp. 103-127, 2014, pp. 203-254). See also Hottois (2002, p. 94).
} 
does one live in the techno-geographic milieu? Writing mainly from the 60's to the 80 's, Simondon criticizes both the underestimation of technique by the ruling class educated only to humanities, and the alienation of technique by a ruling class educated only to economics, but he actually does not deal with the techno-geographical reality itself as a political place, the organisation of which could be a matter of common interest. In the last part of Du mode d'existence des objets techniques, he only suggests, tentatively (and in my opinion meekly), that the important technological "points of convergence" ("point de reticulation," like the Eiffel tower) organise public space like the important religious "points of convergence" (like a cathedral) organise religious space, and that the former should be regarded in similar terms as the latter.

Only in the résumé of a lecture course from 1980 Art et nature Simondon extends his reflection to ecological considerations. ${ }^{54}$ In this text, he affirms the finitude of man and criticizes short-sighted faith in infinite progress. He singles out nuclear power as a particularly dangerous way of jeopardizing human future. Nevertheless he is opposed to the kind of ecology that turns its back to technique and thinks that the repairing of dangerous technogeographical situations is essentially a technical challenge. I think that Simondon, evaluating the situation only from the point of view of the human beings' right and wrong decisions, does not pay sufficient attention to the proper potential of destruction of a technogeographical situation itself. All catastrophies that have their origin in technology are not man-made, or at least not intended by man (for instance the climatic change ${ }^{55}$ ). Also, the possibility of a properly natural or even cosmological catastrophy is a part of a techno-geographic milieu.

Simondon gives a very useful description of our life with technical objects in a techno-geographic milieu. However, he fails to take into account an evasive and uncontrollable aspect of technique, because of which technique will always be both "danger" and "salvation."

Acknowledgements Open access funding provided by University of Helsinki including Helsinki University Central Hospital.

Open Access This article is distributed under the terms of the Creative Commons Attribution 4.0 International License (http://creativecommons.org/licenses/by/4.0/), which permits unrestricted use, distribution, and reproduction in any medium, provided you give appropriate credit to the original author(s) and the source, provide a link to the Creative Commons license, and indicate if changes were made.

\section{References}

Bardin, Andrea. 2015. Epistemology and political philosophy in Gilbert Simondon. Individuation, technics, social systems. Dordrecht: Springer.

\footnotetext{
54 Simondon (2014, pp. 196-200).

55 I explain this in more detail in my article "Technologies of the End of the World" (Lindberg 2017).
} 
Barthélémy, Jean-Hugues. 2005. Penser la connaissance et la technique après Simondon. Paris: L'Harmattan.

Barthélémy, Jean-Hugues. 2014. Simondon. Paris: Les Belles lettres.

Barthélémy, Jean-Hugues. 2015. Life and technology. An inquiry into and beyond Simondon. Leuphana: Meson Press.

Barthélémy, Jean-Hugues. 2016. "Genèse, histoire, et normativité technique”. In Gilbert Simondon ou l'invention du future. Colloque de Cérisy. Sous la direction de Vincent Bontemps, 17-32. Paris: Klincksieck.

Chateau, Jean-Yves. 2008. Le vocabulaire de Simondon. Paris: Ellipses.

Chateau, Jean-Yves. 2010. "La technique. Genèse and concretisation des objets techniques dans Du mode d'existence des objets techniques de Gilbert Simondon". Philopsis, revue numérique. http://www. philopsis.fr/IMG/pdf_Technique-Simondon-Chateau.pdf. Accessed 15 May 2019.

Combes, Muriel. 2006. Tentative d'ouverture d'une boîte noire. Ce que referme la 'question de la technique'. In Technique, monde, individuation. Heidegger, Simondon, Deleuze, ed. Jean-Marie Vaysse, 75-98. Hildesheim: Europaea Memoria, Georg Olms Verlag.

Combes, Muriel. 2013. Gilbert Simondon and the philosophy of the transindividual. Cambridge: MIT Press.

Crawford, Matthew. 2009. Shop class as soulcraft : An inquiry into the value ofwork. New York: Penguin Books.

de Boever, Arne, Alex Murray, Jon Roffe, and Ashley Woodward. 2012. Gilbert Simondon: Being and technology. Edinburgh: Edinburgh University Press.

Grosz, Elizabeth. 2012. Identity and individuation: Some feminist reflections. In Gilbert Simondon: Being and technology, ed. Arne de Boever, Alex Murray, Jon Roffe, and Ashley Woodward. Edinburgh: Edinburgh University Press.

Guchet, Xavier. 2010. Pour un humanisme technologique. Culture, technique et société dans la philosophie de Gilbert Simondon. Paris: Presses Universitaires de France.

Hottois, Gilbert. 2002. Technoscience et technoesthétique. In Simondon, ed. Pascal Chabot. Paris: Vrin.

Leroi-Gourhan, André. 1964. Le geste et la parole. Paris: Albin Michel.

Leroi-Gourhan, André. 1973. Milieu et technique. Paris: Albin Michel.

Lindberg, Susanna. 2017. Technologies of the end of the world. In The End of the World, eds. S. Lindberg, and M. Cavalcante Schuback. London: Rowman and Littlefield International.

Morizot, Baptiste. 2016. Pour une théorie de la rencontre. Hasard et individuation chez G. Simondon. Paris: Vrin.

Parrhesia 07, special issue on Simondon 07.

Sauvagnargues, Anne. 2012. Crystals and membranes: Individuation and temporality. In Gilbert Simondon: Being and technology, ed. Arne de Boever, Alex Murray, Jon Roffe, and Ashley Woodward. Edinburgh: Edinburgh University Press.

Scott, David. 2014. Gilbert Simondon's psychic and collective individuation. Edinburgh: Edinburgh University Press.

Simondon, Gilbert. 2005. L'invention dans les techniques. Cours et conférences. Éd. par Jean-Yves Chateau. Paris: Seuil traces écrites.

Simondon, Gilbert. 2017. On the Mode of Existence of Technical Objects. Translation by Cecile Malaspina and John Rogrove. Minneapolis: Univocal Publishing. The French edition 2012. Du mode d'existence des objets techniques. Paris: Aubier.

Simondon, Gilbert. 2013. L'individuation à la lumière des notions de forme et d'information. Paris: Jérôme Millon.

Simondon, Gilbert. 2014. Sur la technique. Paris: Presses Universitaires de France.

Stiegler, Bernard. 1994. La technique et le temps 1. La faute d'Épiméthée. Paris: Galilée.

Stiegler, Bernard. 2006. Chute et élévation. Apolitique de Simondon. Revue philosophique de la France et de l'étranger 2006 (3): 325-341.

Vaysse, Jean-Marie. 2006. Heidegger et Simondon: Technique et individuation. In Technique, monde, individuation. Heidegger, Simondon, Deleuze, ed. Jean-Marie Vaysse, 5-16. Hildesheim: Europaea Memoria Georg Olms Verlag.

Publisher's Note Springer Nature remains neutral with regard to jurisdictional claims in published maps and institutional affiliations. 